\title{
PENILAIAN KAWASAN PERUMAHAN DENGAN PENDEKATAN KONSEP BERKELANJUTAN (GREENSHIP NEIGHBORHOOD ASSESSMENT)
}

\author{
Sapitri ${ }^{1)}$ dan Zarnold Aziz ${ }^{1)}$ \\ 1) Jurusan Teknik Sipil FT UIR, Jl. Kaharuddin Nasution No.113 Pekanbaru, Riau
}

\begin{abstract}
Global warming and environmental degradation are still being issues in various countries, including Indonesia. It has been causing the climate change. In 2015 the United Nations started a program called Sustainable Development Goals (SDGs). One of the goals was to tackle climate change. In order to encourage the implementation of SDGs, an effort that could conduct was the realization of green housing areas. An assesment is needed to make sure that sustainable development in neighborhood is implemented well and correct. Green Building Council Indonesia (GBCI) has published a rating system called Greenship Neighborhood as a reference for assessing the concept of sustainable development neighbourhood. The purpose of this study was to find out how the implementation of Greenship Neighbourhood and how much value is achieved in Citraland residential area. The method that used were descriptive qualitative and quantitative. Descriptive qualitative was a description of the research object conditions, while descriptive quantitative was output assessments numbers based on the Greenship Neighborhood assessment tool. There were seven aspects that assessed i.e. land ecological enhancement, movement and connectivity, water management and conservation, solid and material waste, community wellbeing strategy, buildings and energy, and innovation future development. The results of research showed that there were six of the seven assessment categories have been applied in the object area. Generaly, the total value is 36 out of 124, with percentage achieved 29\%. Based on these result, Citraland Pekanbaru residential area did not meet the minimum standard for the application of Greenship Neigborhood according to GBCI.
\end{abstract}

Key Words: GBCI, greenship neighborhood, SDGs, sustainable development, sustainable neighborhood,

\section{PENDAHULUAN}

Pemanasan global (global warming) menjadi isu di berbagai negara, termasuk Indonesia. Hal ini dapat terlihat dari peristiwa kekeringan, kebakaran hutan, rusaknya ekosistem terumbu karang, dan mencairnya es di kutub. Akar permasalahan dari pemanasan global sangat kompleks. Beberapa faktor yang mempengaruhi hal tersebut, antara lain: degradasi lingkungan (pembakaran dan penebangan hutan secara sembarangan), pemborosan pemakaian energi listrik, pembakaran sampah secara berlebihan, serta polusi udara yang disebabkan oleh pabrik industri dan kendaraan bermotor. Salah satu dampak dari pemanasan global adalah perubahan iklim dan cuaca (climate change).

Pada tahun 2015, PBB memulai program yang disebut Sustainable Development Goals (SDGs). Tujuan program pembangunan berkelanjutan tersebut yaitu untuk mengatasi perubahan iklim, mengakhiri kemiskinan, mengurangi kesenjangan dan melindungi lingkungan.

Salah satu usaha untuk mendorong terwujudnya pembangunan berkelanjutan adalah penerapan kawasan perumahan hijau. Pembangunan kawasan berkelanjutan adalah suatu pembangunan untuk merespon kebutuhan masyarakat saat ini tanpa mengorbankan kemampuan masyarakat dimasa mendatang (Blum \& Grant, 2006). Selain tanpa mengorbankan kebutuhan untuk generasi di masa mendatang, dibutuhkan juga daya dukung lingkungan sebagai titik beratnya, keberlanjutan ekonomi, dan pencapaian keadilan sosial (Kementrian PUPR - Ditjen Cipta Karya, 2016). Kawasan berkelanjutan idealnya menciptakan suasana yang aman, inklusif, terencana dengan baik, dibangun dan dioperasikan, serta menyediakan layanan yang baik untuk semua masyarakat (Accord, 2005).

Green Building Council Indonesia (GBCI) merupakan lembaga sertifikasi konsep bangunan hijau di Indonesia, telah mengeluarkan salah satu sistem rating yang dinamakan Greenship Neighborhood sebagai acuan penilaian untuk konsep pembangunan kawasan berkelanjutan. Greenship Neighborhood terakhir dikeluarkan oleh GBCI pada Desember 2015, yang disebut dengan Greenship Neighborhood Version 1.0.

Penelitian terkait pengukuran greenship yang dilakukan oleh Ronim \& Talidah (2019) pada kawasan wisata bandar ecopark menunjukkan 
bahwa sertifikat yang sejauh ini diraih hanya sampai taraf silver. Hal tersebut dipengaruhi oleh faktor kurang lengkapnya sarana yang menjadi tolok ukur greenship. Sadjarwo \& Sutandi (2017) yang menilai 2 (dua) kawasan perumahan, juga menunjukkan hasil perolehan sertifikat yang diraih hanya pada tingkat silver dan bronze. Faktor-faktor yang dinilai kurang memenuhi aspek greenship pada penelitian tersebut yaitu belum adanya sistem penghematan energi listrik yang menggunakan energi alternatif dan penggunaan air alternatif untuk kebutuhan air bersih dalam kawasan, belum adanya manajemen dan konservasi air, serta belum adanya inovasi dan pengembangan masa depan kawasan.

Pekanbaru merupakan kota yang berkembang cukup pesat dan salah satu kota terbaik untuk berinvestasi di bidang properti perumahan (Hidayat, 2015). Data Dinas Penanaman Modal dan Pelayanan Terpadu Satu Pintu (2019) Pekanbaru mencatat bahwa terjadi peningkatan izin perumahan pada tahun 2019 dari tahun sebelumnya, yaitu sebesar 175 izin perumahan. Namun, mengacu kepada informasi yang diperolah dari GBCI, sampai saat ini belum ada kawasan perumahan di Pekanbaru tersebut yang tersertifikasi oleh GBCI meskipun beberapa kawasan perumahan yang berada di Pekanbaru telah mengusung konsep green. Berkenaan dengan hal tersebut, maka dipandang perlu dilakukan studi mengenai penerapan Greenship Neighborhood Version 1.0 untuk mengetahui bagaimana penerapannya di kawasan perumahan di Pekanbaru.

Kawasan perumahan Citraland Pekanbaru merupakan salah satu kawasan perumahan kelas menengah atas di Pekanbaru dan telah mengusung konsep clean, green, dan modern (Kusumaputera, 2011). Berdasarkan konsep tersebut maka kawasan perumahan Citraland Pekanbaru sesuai untuk dijadikan objek penelitian.

Secara umum, tujuan dari penelitian ini adalah untuk mengetahui sejauh mana penerapan kategori Greenship Neighborhood Version 1.0 pada kawasan perumahan Citraland Pekanbaru, dan mengetahui perolehan nilai beserta bobotnya pada kawasan tersebut.

\section{METODOLOGI}

Penelitian ini difokuskan pada penerapan sistem perangkat penilaian Greenship Neighborhood Version 1.0 dalam menganalisis berapa persen tingkat pencapaian standard greenship yang diperoleh oleh kawasan yang diteliti. Penelitian ini tidak membahas secara detail setiap tolak ukur dari Greenship Neighborhood Version 1.0. dan tidak menyajikan tentang alur proses sertifikasi Greenship pada kawasan terkait. Objek penelitian hanya pada perumahan Citraland Pekanbaru dengan luas area yang diteliti adalah 16 ha dari 24 ha luas keseluruhan seperti yang terlihat pada Gambar 1.

Dalam menganalisis hasil penelitian digunakan metode deskriptif kualitatif dan kuantitatif. Deskriptif kualitatif yaitu menguraikan tentang kondisi yang sedang terjadi pada objek penelitian, sedangkan deskriptif kuantitatif yang dimaksud adalah menghasilkan keluaran penilaian dalam bentuk angka dengan menggunakan sistem perangkat penilaian Greenship Neigborhood Version 1.0.

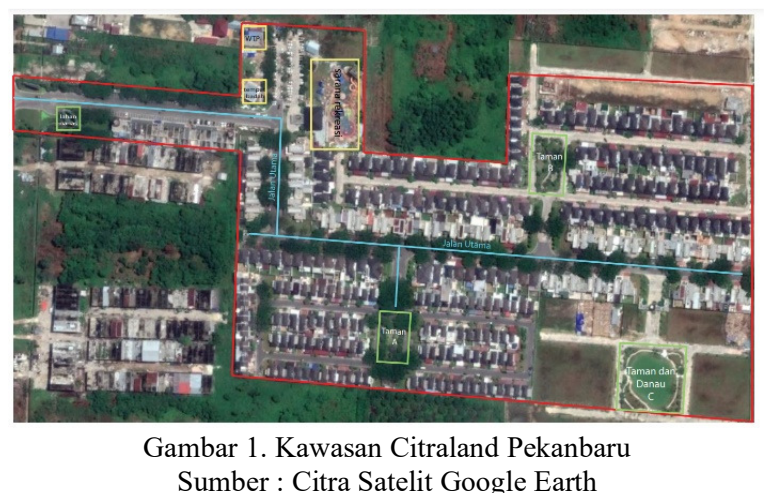

Teknik pengumpulan data primer dilakukan dengan observasi langsung ke kawasan melalui izin dari pihak developer, dan melakukan wawancara dengan pihak developer. Proses wawancara dilakukan terhadap pihak supervisor developer Perumahan Citraland Pekanbaru, karena pihak supervisor sangat memahami kondisi kawasan. Tujuan wawancara ini untuk melengkapi data observasi kawasan yang akan dianalisis. Untuk menunjang penelitian dalam mencapai tujuannya data sekunder berupa masterplan kawasan juga dibutuhkan.

Setelah pengumpulan data dilakukan, dilanjutkan dengan analisa data, yaitu mengidentifikasi penerapan Greenship Neighborhood di kawasan yang diteliti. Berikutnya dilakukan kuantifikasi terhadap penerapan kriteria Greenship Neighborhood untuk mengetahui pencapaian bobot dan nilai yang diperoleh oleh kawasan tersebut. Untuk memastikan bahwa metode/teknik dan analisis data pada penelitian ini sudah tepat, maka komunikasi interaktif via email kepada pihak Greenship Professional (GP) dilakukan secara continue.

Penilaian Greenship Neighborhood memiliki 7 (tujuh) kategori yang harus diterapkan untuk mewujudkan kawasan berkelanjutan. Ke-tujuh kategori tersebut dapat dilihat pada Tabel 1.

Dari Tabel 1, dapat dilihat bahwa pencapaian $100 \%$ berdasarkan perangkat penilaian Greenship Neighborhood adalah 124 poin. Angka tersebut menjadi dasar menentukan peringkat penilaian 
Cantilever $\mid$ Volume: 10 Nomor: 01 April 2021 | ISSN: 1907-4247 (Print) | ISSN: 2477-4863 (Online) $\mid$ Website: http://cantilever.id

Sapitri \& Zarnol Aziz | Penilaian Kawasan Perumahan dengan Pendekatan Konsep Berkelanjutan (Greenship Neighborhood Assessment)

untuk Greenship Neighborhood dari persentase yang telah ditetapkan GBCI. Peringkat penilaian tersebut seperti yang diperlihatkan pada Tabel 2.

Tabel 1. Kategori Penilaian Pada Greenship Neighborhood (GBCI, 2015)

\begin{tabular}{clcc}
\hline No. & \multicolumn{1}{c}{ Kategori } & Nilai & Bobot \\
\hline 1 & Land Ecological Enhancement (LEE) & 19 & $15 \%$ \\
2 & Movement and Connectivity (MAC) & 26 & $21 \%$ \\
3 & Water Management and & 18 & $15 \%$ \\
& Conservation (WMC) & 16 & $13 \%$ \\
4 & Solid Waste and Material (SWM) & 16 & $13 \%$ \\
5 & Community Wellbeing Strategy & 18 & $15 \%$ \\
& (SWM) & 11 & $9 \%$ \\
7 & Building and Energy (BAE) & 124 & $100 \%$ \\
\hline & Innovation and Future Development & & \\
& (IFD) & & \\
\hline
\end{tabular}

Tabel 2. Peringkat Penilaian Greenship Neighborhood (GBCI, 2015)

\begin{tabular}{|c|c|c|}
\hline Peringkat & Persentase & Perolehan Poin Minimum \\
\hline Platinum & $73 \%$ & 90 \\
\hline Gold & $57 \%$ & 71 \\
\hline Silver & $46 \%$ & 57 \\
\hline Bronze & $35 \%$ & 43 \\
\hline
\end{tabular}

\section{HASIL DAN PEMBAHASAN}

Sebelum melanjutkan kriteria penilaian Greenship Neigborhood, ada beberapa persyaratan yang harus dipenuhi kawasan yang telah ditetapkan oleh GBCI. Kawasan Perumahan Citraland Pekanbaru dikategorikan sebagai Built Project maka persyaratan yang harus dipenuhi kawasan tersebut dapat dilihat pada Tabel 3 .

Tabel 3. Pemenuhan Kelayakan Kawasan Perumahan Citraland Pekanbaru

\begin{tabular}{clc}
\hline No. & \multicolumn{1}{c}{ Kelayakan } & Keterangan \\
\hline 1. & Rencana induk (masterplan) kawasan. & terpenuhi \\
\hline 2. & $\begin{array}{l}\text { Terpenuhi 2 izin lingkungan atau surat } \\
\text { kelayakan lingkungan hidup atau } \\
\text { rekomendasi UKL/UPL dan izin terkait. }\end{array}$ & terpenuhi \\
\hline 3. & $\begin{array}{l}\text { Minimum luas kawasan adalah } 5000 \mathrm{~m} 2 \\
\text { dan maksimum 60 Ha }\end{array}$ & terpenuhi \\
\hline 4. & Minimum terdiri atas 2 (dua) bangunan. & terpenuhi \\
\hline 5. & Satu Pengelola & terpenuhi \\
\hline 6. & $\begin{array}{l}\text { Kesediaan data kawasan untuk diakses } \\
\text { GBC Indonesia terkait proses sertifikasi. }\end{array}$ & terpenuhi \\
\hline
\end{tabular}

Berdasarkan Tabel 3, dapat dilihat bahwa hasil pemeriksaan pada semua persyaratan yang ditetapkan oleh GBCI telah terpenuhi, sehingga pada Kawasan Perumahan Citraland Pekanbaru dapat dilakukan penilaian berdasarkan kriteria penilaian Greenship Neighborhood Version 1.0.

Terdapat tujuh kategori penilaian pada Greenship Neighborhood Version 1.0. Pada kategori 1 s.d 4, terdapat terdapat istilah kriteria prasyarat, dimana kriteria prasyarat ini harus terpenuhi terlebih dahulu baru bisa dilanjutkan penilaian terhadap kriteria kredit. Kriteria prasyarat ini tidak memiliki nilai, tetapi hanya berupa hasil pemeriksaan terhadap dokumen, observasi langsung ke lokasi dan hasil wawancara kepada responden terhadap item prasyarat yang ada pada perangkat penilaian. Untuk

kriteria 5 sd 7 tidak dapat prasyarat yang harus dipenuhi sehingga penilaian dapat langsung dilakukan terhadap kriteria kredit.

Merujuk kepada data hasil observasi dan wawancara di lapangan serta Masterplan Kawasan Perumahan Citraland Pekanbaru, maka hasil penilaian berdasarkan tujuh kategori pada Greenship Neighborhood dapat dijabarkan sebagai berikut.

\section{Peningkatan Ekologi Lahan - Land Ecological Enhancement (LEE)}

Hasil dari penilaian berdasarkan kategori Land Ecological Enhancement (LEE) disajikan dalam Tabel 4. Dasar dari pengukuran perolehan nilai yaitu berdasarkan indikator-indikator yang telah ditetapkan oleh perangkat penilaian. Pada tabel tersebut dapat diketahui perolehan nilai pada kategori peningkatan ekologi lahan di kawasan Citraland Pekanbaru.

Tabel 4. Penilaian Kategori LEE

\begin{tabular}{|c|c|c|}
\hline Kriteria dan Indikator Penilaian & $\begin{array}{c}\text { Nilai } \\
\text { Maksimum }\end{array}$ & $\begin{array}{c}\text { Perolehan } \\
\text { Nilai }\end{array}$ \\
\hline \multicolumn{3}{|l|}{ LEE P (Area dasar hijau) } \\
\hline $\begin{array}{l}\text { Kawasan memiliki Ruang Terbuka Hijau } \\
\text { (RTH) sebagai sarana interaksi manusia dan } \\
\text { alam. (Prasyarat) }\end{array}$ & $\begin{array}{c}\text { Tidak } \\
\text { memiliki } \\
\text { nilai }\end{array}$ & Terpenuhi \\
\hline \multicolumn{3}{|l|}{ LEE 1 (Area hijau untuk publik) } \\
\hline $\begin{array}{l}\text { Menyediakan ruang terbuka hijau untuk } \\
\text { publik minimal } 25 \% \text { dari luas lahan ( } 3 \text { poin) } \\
\text { atau, menyediakan ruang terbuka hijau untuk } \\
\text { publik minimal } 35 \% \text { dari luas lahan ( } 4 \text { poin). }\end{array}$ & 4 & 0 \\
\hline \multicolumn{3}{|l|}{ LEE 2 (Pelestarian Habitat) } \\
\hline $\begin{array}{l}\text { 1) Kawasan mempertahankan pohon besar } \\
\text { yang telah dewasa, yang ada dalam kawasa } \\
\text { minimal } 20 \% \text { ( } 2 \text { poin). }\end{array}$ & & \\
\hline \multirow{2}{*}{$\begin{array}{l}\text { 2) Memiliki rencana pengelolaan tanaman } \\
\text { lokal provinsi berupa pepohonan dan / atau } \\
\text { semak di dalam kawasan dengan persentas } \\
\text { tanaman asli } 30 \%-60 \% \text { (1 poin) dan } \\
\text { apabila lebih dari } 60 \% \text { (2 poin). Atau } \\
\text { memiliki rencana perlindungan fauna, atau } \\
\text { rencana untuk meningkatkan keragaman } \\
\text { fauna lokal ( } 2 \text { poin). }\end{array}$} & & \\
\hline & 6 & 4 \\
\hline $\begin{array}{l}\text { 3) Penanaman minimal } 10 \text { anakan pohon mud } \\
\text { untuk setiap pohon di dalam kawasan yang } \\
\text { tumbang dan ditumbangkan ( } 2 \text { poin). }\end{array}$ & & \\
\hline \multicolumn{3}{|l|}{ LEE 3 (Revitalisasi lahan) } \\
\hline $\begin{array}{l}\text { Melakukan revitalisasi dan pembangunan di } \\
\text { atas lahan yang bernilai negatif dan tak } \\
\text { terpakai karena bekas pembangunan atau } \\
\text { dampak negatif pembangunan di dalam } \\
\text { kawasan, dengan persentase dari luas minima } \\
\text { lahan yang ter-revitalisasi } 50 \% \text { ( } 1 \text { poin) atau } \\
100 \% \text { (4 poin). }\end{array}$ & 4 & 0 \\
\hline \multicolumn{3}{|l|}{ LEE 4 (Iklim mikro) } \\
\hline $\begin{array}{l}\text { Menunjukan upaya peningkatan kualitas iklin } \\
\text { mikro untuk ruang publik kawasan. Dengan } \\
\text { ketentuan persentase dari total ruang publik } \\
40 \% \text { ( } 1 \text { poin), } 60 \% \text { ( } 2 \text { poin) atau } 80 \% \text { ( } 3 \text { poin }\end{array}$ & 3 & 3 \\
\hline \multicolumn{3}{|l|}{ LEE 5 (Lahan produktif) } \\
\hline $\begin{array}{l}\text { Menyediakan lahan untuk produksi sayur } \\
\text { dan buah lokal untuk memenuhi kebutuhan } \\
\text { masyarakat setempat dengan luas terhadap } \\
\text { RTH } \leq 10 \% \text { ( } 1 \text { poin) atau }>10 \% \text { ( } 2 \text { poin). }\end{array}$ & 2 & 1 \\
\hline Jumlah & 19 & 8 \\
\hline
\end{tabular}


Berdasarkan Tabel 4, hasil penelitian menunjukkan bahwa kriteria prasyarat (LEE P) telah terpenuhi. Prasyarat tersebut yaitu area dasar hijau. Terpenuhinya kriteria prasyarat tersebut memberikan indikasi bahwa penilaian lebih lanjut dapat dilakukan terhadap kriteria LEE 1 sampai LEE 5. Secara umum perolehan nilai total pada kategori ini adalah 8 dari nilai maksimum 19. Kecilnya nilai yang diperoleh disebabkan oleh adanya kriteria yang tidak terpenuhi, yaitu kriteria LEE 1 dan LEE 3. Belum maksimalnya RTH publik yang dimiliki yaitu hanya 3,86\% dari luas lahan, dan tidak adanya revitalisasi lahan pada kawasan ini, menyebabkan kedua kriteria tersebut memperoleh nilai nol.

Untuk kriteria LEE 2 memperolah nilai 4 karena berdasarkan hasil observasi pada kawasan ditemukan adanya penanaman lebih dari 10 anakan pohon muda jenis ketapang kencana, dan terdapat lebih dari $20 \%$ pohon dewasa sebagai upaya untuk menyeimbangkan kualitas lingkungan dari dampak pembukaan lahan. Disamping itu, pada kawasan ini juga menunjukkan adanya upaya peningkatan kualitas iklim mikro dengan adanya pohon pelindung (pohon trambesi) disepanjang jalan utama, sehingga pada kriteria LEE 4 mendapatkan nilai 3. Untuk LEE 5, hanya didapatkan poin 1 karena kawasan hanya memiliki lahan yang kurang dari $10 \%$ untuk produksi buah.

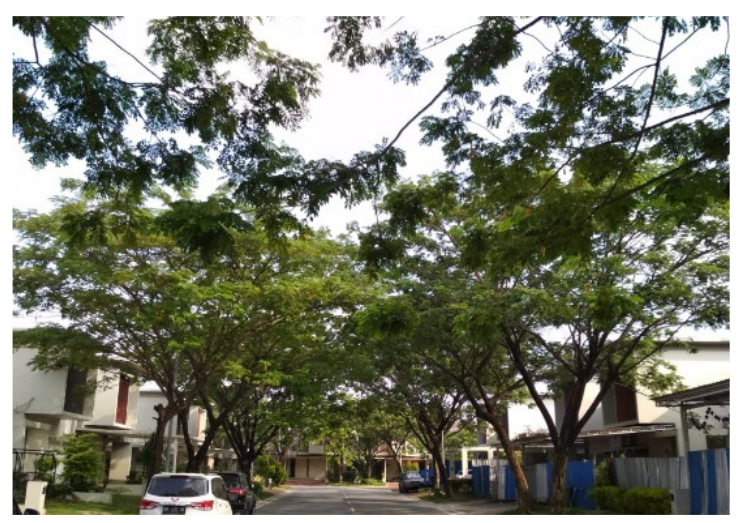

Gambar 2. Pohon Trambesi di kawasan perumahan

\section{Pegerakan dan Konektivitas - Movement and Connectivity (MAC)}

Hasil dari perolehan nilai pada kategori pergerakan dan konektivitas dapat dilihat pada Tabel 5. Pada kategori ini, terdapat tiga kriteria prasyarat dan enam kriteria kredit. Berdasarkan hasil observasi dilapangan, kawasan objek penelitian tidak melakukan studi tentang aksesibilitas (MAC P1) dan kawasan tidak terkoneksi dengan jaringan transportasi umum (MAC P2 dan MAC P3). Tidak adanya fasilitas pada jalan dapat dilihat pada Gambar 3.
Tabel 5. Penilaian Kategori MAC

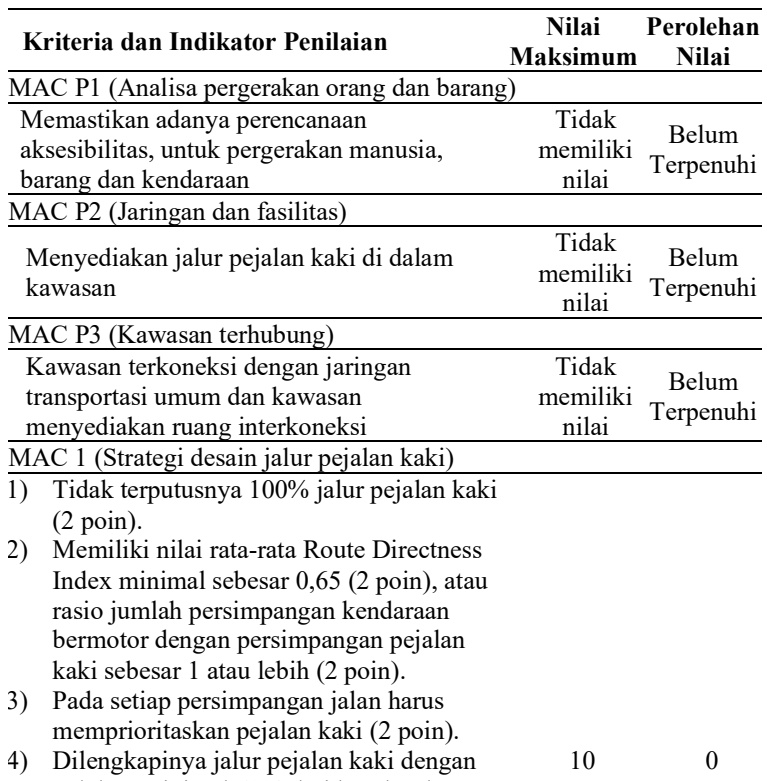
jalur pejalan kaki (2 poin).

5) Menyediakan akses yang aman dan bebas dari perpotongan dengan akses kendaraan bermotor dalam menghubungkan secara langsung bangunan dengan bangunan lain (4 poin).

6) Membuat lingkungan yang menari bagi pejalan kaki ( 2 poin).

MAC 2 (Transportasi umum)

1) Memenuhi tujuh prasarana dasar (1 poin). Atau memenuhi tujuh prasarana dasar dan memenuhi minimal dua prasarana lain (2 poin).

$6 \quad 0$

2) Terdapat minimum enam jenis sarana dalam radius $400 \mathrm{~m}$ ( 1 poin).

MAC 3 (Utilitas dan fasilitas umum)

1) Memenuhi tujuh prasarana dasar (1 poin). Atau memenuhi tujuh prasarana dasar dan memenuhi minimal dua prasarana lain (2 poin).

2) Terdapat minimum enam jenis sarana dalan radius $400 \mathrm{~m}$ ( 1 poin).

MAC 4 (Aksesibilitas universal)

1) Kawasan memberikan kelancaran dan kemudahan jalur pada ruang publik bagi semua orang ( 2 poin).

2) Menyediakan pada titik-titik tertentu fasilitc khusus bagi semua orang (1 poin).

MAC 5 (Jaringan dan tempat penyimpanan sepeda)

1) Di dalam kawasan menyediakan jalur sepeda, yang bebas dari persinggungan sejajar dengan kendaraan bermotor dengan rasio jalur sepeda terhadap total panjang jalan $50 \%$ ( 1 poin) atau $100 \%$ ( 3 poin).

2) Menyediakan tempat parkir yang aman bagi sepeda dalam kawasan (minimal salah satu) gerbang kawasan, taman, dan tempat pergantian moda transportasi umum (1 poin).

MAC 6 (Parkir bersama)

1) Menyediakan fasilitas parkir yang bersifat publik (1 poin).

2) Menghindari on street parking (1 poin).

3) Mengurangi on surface parking, dengan pembatasan penggunaan lahan untuk parkir, maksimal $10 \%$ dari lahan total $(1$ poin). Jumlah 
Cantilever $\mid$ Volume: 10 Nomor: 01 April $2021 \mid$ ISSN: 1907-4247 (Print) $\mid$ ISSN: 2477-4863 (Online) $\mid$ Website: http://cantilever.id

Sapitri \& Zarnol Aziz | Penilaian Kawasan Perumahan dengan Pendekatan Konsep Berkelanjutan (Greenship Neighborhood Assessment)

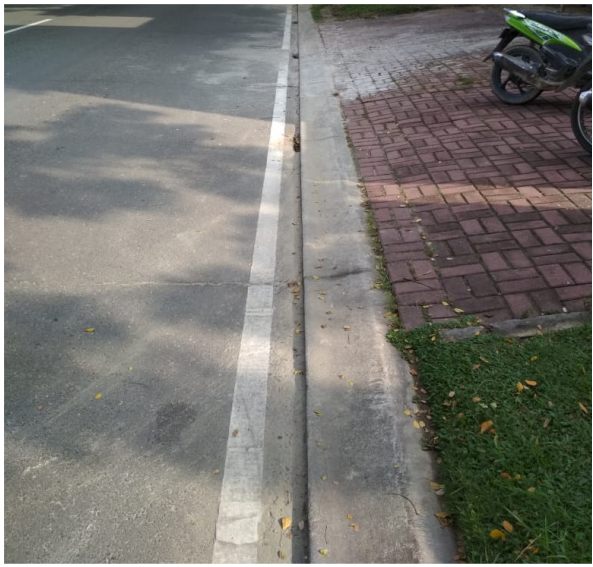

Gambar 3. Kondisi jalan di kawasan

Pada Gambar 3 terlihat bahwa kawasan tersebut tidak memiliki jalur khusus untuk pejalan kaki yang menyebabkan kriteria prasyarat MAC P2 belum terpenuhi. Pada kategori ini, secara keseluruhan nilai yang diperoleh adalah 0 (nol) dari nilai maksimum 26. Hal tersebut disebabkan karena tidak ada satupun kriteria prasyarat yang terpenuhi meskipun terdapat 2 kriteria kredit yang memiliki nilai. Nilai kriteria kredit tidak dapat diperhitungkan atau diabaikan jika kriteria prasyarat tidak terpenuhi. Hal ini sejalan dengan hasil wawancara/komunikasi yang bersifat crosscheck dengan pihak ahli (Greenship Professional).

\section{Manajemen dan Konservasi Air - Water Management and Conservation (WMC)}

Berikut disajikan hasil perolehan nilai pada kategori manajemen dan konservasi air, yang dapat dilihat pada Tabel 6. Tabel 6 menunjukkan bahwa terdapat satu kriteria prasyarat dan empat kriteria kredit pada kategori Water Management and Conservation (WMC).

Pada tabel tersebut, dapat dilihat bahwa kriteria prasyarat telah terpenuhi, karena kawasan mendata jumlah penggunaan air bersih PDAM dalam kawasan setiap bulan, maka penilaian lebih lanjut dapat dilakukan. Hasil MWC 1 s.d 4 menunjukkan jumlah nilai yang sangat rendah, dimana perolehan nilai total dari kriteria kredit adalah 1 dari nilai maksimum 18. Minimnya nilai yang diperoleh karena pada kawasan ini belum dijumpai adanya upaya penggunaan air alternatif seperti air PDAM dan daur ulang air. Kawasan hanya menggunakan air tanah sebagai kebutuhan air bersih, sehingga untuk kriteria WMC 1 mendapat nilai 0 . Perolehan nilai 1 pada kriteria WMC 2 diperoleh karena kawasan melakukan perhitungan limpasan air hujan, namun limpasan air hujan di kawasan ini langsung dialirkan ke drainase kota tanpa adanya upaya untuk mengurangi volume limpasan air hujan tersebut.
Selain itu, kawasan tidak memiliki unit pengolahan limbah cair yang dihasilkan, sehingga kriteria WMC 4 memperoleh nilai nol.

Tabel 6. Penilaian Kategori WMC

\begin{tabular}{|c|c|c|}
\hline Kriteria dan Indikator Penilaian & $\begin{array}{c}\text { Nilai } \\
\text { Maksimum }\end{array}$ & $\begin{array}{c}\text { Perolehan } \\
\text { Nilai }\end{array}$ \\
\hline \multicolumn{3}{|l|}{ WMC P (Skematik air kawasan) } \\
\hline $\begin{array}{l}\text { Mengetahui Penggunaan konsumsi air di } \\
\text { dalam kawasan (prasyarat) }\end{array}$ & $\begin{array}{l}\text { Tidak } \\
\text { memiliki } \\
\text { nilai }\end{array}$ & Terpenuhi \\
\hline \multicolumn{3}{|l|}{ WMC 1 (Air alternatif) } \\
\hline $\begin{array}{l}\text { Untuk memenuhi kebutuhan air bersih, } \\
\text { kawasan menggunakan air alternatif dengan } \\
\text { persentase air alternatif } 10 \% \text { ( } 2 \text { poin), } 30 \% \text { ( } 4 \\
\text { poin), atau } 50 \% \text { ( } 6 \text { poin). Atau penggunaan } \\
\text { air alternatif untuk memenuhi semua } \\
\text { kebutuhan irigasi kawasan ( } 1 \text { poin) }\end{array}$ & 4 & 0 \\
\hline \multicolumn{3}{|l|}{ WMC 2 (Manajemen limpasan air) } \\
\hline $\begin{array}{l}\text { 1) Melakukan perhitungan analisa limpasan } \\
\text { hujan kawasan ( } 1 \text { poin). }\end{array}$ & & \\
\hline 2) Meminimalisir volume limpasan air hujan & & \\
\hline $\begin{array}{l}\text { kawasan ke drainase kota, dengan } \\
\text { persentase volume limpasan air hujan } 25 \% \\
(2 \text { poin), } 50 \% \text { ( } 3 \text { poin), atau } 75 \% \text { ( } 4 \text { poin). }\end{array}$ & 7 & 1 \\
\hline $\begin{array}{l}\text { 3) Memenuhi tolok ukur } 2 \text { (dua), minimal } 2 \\
\text { (dua) nilai dan membantu mengurangi } \\
\text { aliran limpasan hujan dari luar kawasan ( } 2 \\
\text { poin). }\end{array}$ & & \\
\hline \multicolumn{3}{|l|}{ WMC 3 (Pelestarian badan air dan lahan basah) } \\
\hline $\begin{array}{l}\text { Apabila kawasan tidak terdapat dan atau } \\
\text { bersinggungan badan air dan lahan basah mak } \\
\text { indikator pada WMC } 3 \text { tidak berlaku : }\end{array}$ & & \\
\hline $\begin{array}{l}\text { 1) Menjaga zona penyangga badan air atau } \\
\text { lahan basah, pada jarak yang sesuai dengan } \\
\text { peraturan ( } 1 \text { poin). }\end{array}$ & 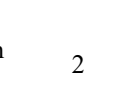 & 0 \\
\hline \multicolumn{3}{|l|}{$\begin{array}{l}\text { 2) Memenuhi Tolok Ukur } 1 \text { (Satu) dan } \\
\text { melakukan upaya konservasi di dalam zona } \\
\text { penyangga badan air atau lahan basah (1 } \\
\text { poin). }\end{array}$} \\
\hline \multicolumn{3}{|l|}{ WMC 4 (Manajemen limbah cair) } \\
\hline $\begin{array}{l}\text { Tersedianya unit pengolahan untuk seluruh } \\
\text { limbah cair yang dihasilkan di dalam } \\
\text { kawasan }\end{array}$ & 3 & 0 \\
\hline Jumlah & 18 & 1 \\
\hline
\end{tabular}

\section{Limbah Padat dan Material - Solid Waste and Material (SWM)}

Perolehan penilaian terhadap kategori limbah padat dan material di kawasan Citraland Pekanbaru dapat dilihat pada Tabel 7. Tabel 7 menunjukkan bahwa terdapat satu kriteria prasyarat dan empat kriteria kredit. Kriteria prasyarat sudah terpenuhi karena dalam kawasan terdapat fasilitas pemilahan untuk sampah organik dan sampah anorganik. Terpenuhinya kriteria prasyarat maka selanjutnya dapat dilakukan dilakukan penilaian terhadap kriteria SWM 1 sampai SWM 4.

Berdasarkan hasil wawancara dengan responden, manajemen limbah tingkat lanjut (SWM 1) telah dilakukan dengan cara mengolah sampah yang dapat digunakan kembali dan/atau yang dapat didaur ulang dan mengelola sampah/limbah yang mengandung bahan berbahaya dan beracun baik secara mandiri atau bekerja sama dengan badan resmi pengolahan sampah yang ada di kota Pekanbaru. Terkait manajemen limbah konstruksi 
(SWM 2) diperoleh nilai 3, karena: telah melakukan penanganan sampah dari kegiatan bongkaran bangunan; melakukan perlindungan terhadap lapisan atas tanah (topsoil); telah memiliki pedoman pengelolaan limbah padat, cair, dan polusi udara dari debu dan partikulat selama masa konstruksi kawasan.

Tabel 7. Penilaian Kategori SWM

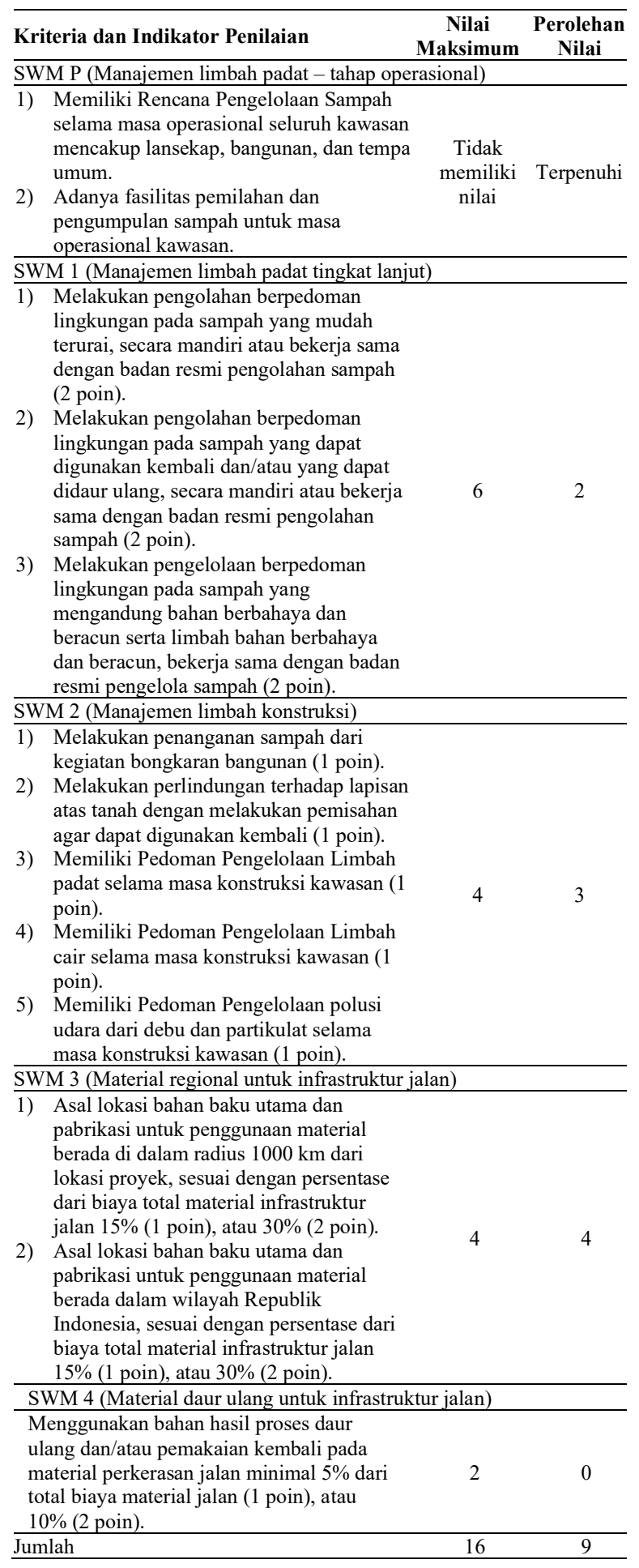

Terkait kebutuhan material untuk infrastruktur jalan, kawasan menggunakan material yang berasal dari Pekanbaru yang tidak jauh dari lokasi proyek. Hal tersebut memenuhi kriteria SWM 3 sehingga mendapat nilai 4. Namun demikian, belum ada temuan penggunaan bahan material daur ulang untuk infrastruktur jalan, maka untuk kriteria SWM 4 meperoleh nilai 0. Berdasarkan hal-hal tersebut, maka secara umum total perolehan nilai yang didapat pada kategori Solid Waste and Material (SWM) adalah 9 dari nilai maksimum 16.

\section{Strategi Kesejahteraan Masyarakat - Community Wellbeing Strategy (CWS)}

Keseluruhan hasil perolehan nilai untuk kategori strategi kesejahteraan masyarakat dapat dilihat pada Tabel 8. Dapat dilihat pada Tabel 8 bahwa kategori ini memiliki enam kriteria kredit dan tidak memiliki kriteria prasyarat. Karena tidak mempunyai kriteria prasyarat, maka dapat langsung dilakukan penilaian terhadap kriteria CWS 1 sampai CWS 6. Secara umum, nilai yang diperoleh pada kategori ini adalah 10 dari nilai maksimum 16. Berdasarkan tabel tersebut 4 dari kriteria mendapatkan nilai maksimum dari standard nilai yang ada.

Perolehan nilai total yang cukup baik pada kategori ini dikarenakan dalam kawasan perumahan terdapat fasilitas agar masyarakat dapat saling berinteraksi dan beraktivitas seperti taman dan lapangan olahraga (kriteria CWS 1 mendapat nilai 2). Selain hal tersebut, pihak developer kawasan juga telah menyelenggarakan survei kepuasan kepada penghuni secara rutin sekali dalam enam bulan, dan menggunakan whatsapp group sebagai sarana komunikasi dengan perwakilan warga. Hasil observasi juga menunjukkan bahwa kawasan perumahan telah dilengkapi dengan fasilitas bagi masyarakat yang dapat digunakan untuk kegiatan sosial ekonomi antara lain waterpark, aula, dan tempat ibadah, sehingga memperoleh nilai maksimum 4 pada kriteria CWS 2. Namun demikian, hasil wawancara menunjukan bahwa masyarakat kawasan belum menyelenggarakan promosi gaya hidup berkelanjutan yang bersifat konsisten atau berkala seperti kegiatan gotong royong, pengedukasian yang bekaitan dengan lingkungan, atau kegiatan lainnya (CWS 3 bernilai $0)$.

Kriteria CWS 4 memperoleh nilai 2 karena kawasan menyediakan lokasi selain hunian untuk pengembangan sektor bisnis dan komersial yaitu terdapat 20 unit ruko tiga lantai yang terlelak dibagian depan kawasan tersebut. Mengenai upaya keamanan, kawasan dijaga security dan dipantau CCTV selama 24 jam sehingga pada kriteria CWS 6 mendapatkan nilai 2. Namun, dalam aspek penilaian kebudayaan lokal, kawasan tidak memperhatikan 
Cantilever $\mid$ Volume: 10 Nomor: 01 April $2021 \mid$ ISSN: 1907-4247 (Print) $\mid$ ISSN: 2477-4863 (Online) $\mid$ Website: http://cantilever.id

Sapitri \& Zarnol Aziz | Penilaian Kawasan Perumahan dengan Pendekatan Konsep Berkelanjutan (Greenship Neighborhood Assessment)

pelestarian dan pengembangan budaya lokal karena

konsep kawasan yang bersifat western, sehingga

kriteria CWS 5 memperoleh nilai nol.

Tabel 8. Penilaian Kategori CWS

\begin{tabular}{|c|c|c|}
\hline Kriteria dan Indikator Penilaian & $\begin{array}{c}\text { Nilai } \\
\text { Maksimum }\end{array}$ & $\begin{array}{c}\text { Perolehan } \\
\text { Nilai }\end{array}$ \\
\hline \multicolumn{3}{|l|}{ CWS 1 (Fasilitas bagi masyarakat) } \\
\hline $\begin{array}{l}\text { Menyediakan sarana untuk interaksi dan } \\
\text { aktivitas masyarakat, setiap minimal radius } \\
400 \mathrm{~m} \text { ( } 2 \text { poin). }\end{array}$ & 2 & 2 \\
\hline \multicolumn{3}{|l|}{ CWS 2 (Manfaat sosial dan ekonomi) } \\
\hline $\begin{array}{l}\text { 1) Menyerahkan hasil studi atas } \\
\text { pengembangan ekonomi masyarakat di } \\
\text { dalam dan di luar kawasan yang } \\
\text { berdampak pengembangan kawasan (2 } \\
\text { poin). Atau menyelenggarakan survei } \\
\text { kepuasan kepada penghuni/pekerja di } \\
\text { dalam kawasan mengenai kualitas } \\
\text { lingkungan dan fasilitas kawasan (1 } \\
\text { poin). Memiliki sarana komunikasi } \\
\text { penyampaian pendapat untuk rencana } \\
\text { pengembangan kawasan dengan } \\
\text { perwakilan warga atau asosiasi } \\
\text { masyarakat (1 poin). }\end{array}$ & 4 & 4 \\
\hline $\begin{array}{l}\text { 2) Memiliki prasarana bagi masyarakat, } \\
\text { yang dapat digunakan untuk kegiatan } \\
\text { ekonomi dan sosial ( } 2 \text { poin)2) Adanya } \\
\text { fasilitas pemilahan dan pengumpulan } \\
\text { sampah untuk masa operasional kawasan. }\end{array}$ & & \\
\hline \multicolumn{3}{|l|}{ CWS 3 (Kepedulian masyarakat) } \\
\hline $\begin{array}{l}\text { 1) Menyelenggarakan promosi gaya hidup } \\
\text { berkelanjutan kepada masyarakat di } \\
\text { dalam kawasan minimal } 2 \text { (dua) program } \\
\text { promosi yang bersifat konsisten (1 poin). } \\
\text { 2) Memenuhi tolok ukur 1, setiap } \\
\text { penambahan 1 (satu) program bertambah } \\
1 \text { nilai. (maksimal 3 nilai tambahan) }\end{array}$ & 4 & 0 \\
\hline \multicolumn{3}{|l|}{ CWS 4 (Kawasan campuran) } \\
\hline $\begin{array}{l}\text { Untuk kawasan dominan hunian, } \\
\text { menyediakan lokasi selain hunian minimal } \\
15 \% \text { dari luas zona kawasan untuk } \\
\text { pengembangan sektor bisnis dan komersial } \\
\text { kawasan ( } 2 \text { poin). Atau Untuk kawasan } \\
\text { dominan bukan hunian, menyediakan lokasi } \\
\text { hunian dalam kawasan minimal } 15 \% \text { dari } \\
\text { luas zona kawasan ( } 2 \text { poin). Atau } \\
\text { membuktikan minimal } 10 \% \text { dari orang } \\
\text { bekerja dan tinggal di dalam kawasan atau } \\
\text { dalam jangkauan } 5 \text { km dari tempat } \\
\text { bekerjanya di dalam kawasan ( } 2 \text { poin) }\end{array}$ & 2 & 2 \\
\hline \multicolumn{3}{|l|}{ CWS 5 (Kebudayaan lokal) } \\
\hline $\begin{array}{l}\text { Menerapkan budaya lokal daerah setempat } \\
\text { dalam bentuk minimal } 2 \text { (dua) aspek berikut } \\
\text { ini ( } 1 \text { poin) : fasilitas pendukung } \\
\text { penyelenggaraan kebudayaan lokal, kegiatan } \\
\text { pelestarian budaya lokal, kegiatan edukasi } \\
\text { budaya local penamaan } \\
\text { tempat/bangunan/jalan berdasarkan nama } \\
\text { budaya lokal, arsitektur bangunan } \\
\text { berdasarkan identitas setempat, konservasi } \\
\text { bangunan dan/atau area sejarah,. Atau } \\
\text { Menerapkan budaya lokal dalam bentuk } \\
\text { minimal } 4 \text { aspek yang tercantum (2 poin) } \\
\end{array}$ & 2 & 0 \\
\hline \multicolumn{3}{|l|}{ CWS 6 (Lingkungan yang aman) } \\
\hline $\begin{array}{l}\text { Memiliki upaya penjaminan ketahanan dan } \\
\text { keamanan dalam menanggapi bencana ( } 2 \\
\text { poin). }\end{array}$ & 2 & 2 \\
\hline Jumlah & 16 & 10 \\
\hline
\end{tabular}

\begin{tabular}{|c|c|c|}
\hline Kriteria dan Indikator Penilaian & $\begin{array}{c}\text { Nilai } \\
\text { Maksimum }\end{array}$ & $\begin{array}{c}\text { Perolehan } \\
\text { Nilai }\end{array}$ \\
\hline \multicolumn{3}{|l|}{ BAE 1 (Bangunan hijau greenship) } \\
\hline $\begin{array}{l}\text { Adanya bangunan hijau tersertifikasi } \\
\text { Greenship di dalam kawasan (6 poin) }\end{array}$ & 6 & 0 \\
\hline \multicolumn{3}{|l|}{ BAE 2 (Hunian berimbang) } \\
\hline $\begin{array}{l}\text { Pola pembangunan berimbang yang sesuai } \\
\text { dengan peraturan yang berlaku tentang } \\
\text { hunian berimbang ( } 1 \text { poin). }\end{array}$ & 1 & 0 \\
\hline \multicolumn{3}{|l|}{ BAE 3 (Efisiensi energi dalam kawasan) } \\
\hline 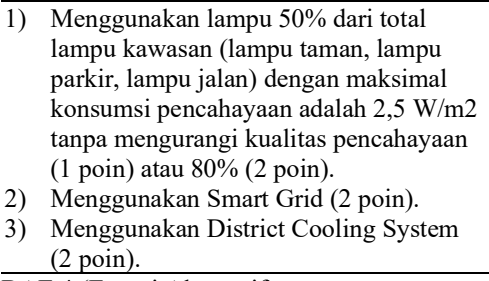 & 4 & 2 \\
\hline \multicolumn{3}{|l|}{ BAE 4 (Energi Alternatif) } \\
\hline $\begin{array}{l}\text { Kawasan menggunakan sumber energi } \\
\text { alternatif. } 20 \% \text { dari kebutuhan energi } \\
\text { kawasan tidak termasuk energi bangunan ( } 1 \\
\text { poin), } 50 \% \text { ( } 2 \text { poin), atau } 80 \% \text { ( } 3 \text { poin) }\end{array}$ & 3 & 0 \\
\hline \multicolumn{3}{|l|}{ BAE 5 (Pengurangan polusi cahaya) } \\
\hline $\begin{array}{l}\text { Memenuhi strategi: Light Trespass, Glare, } \\
\text { Lamp Shielding, dan Sky-Glow } \\
\text { Limitation.( } 2 \text { poin) }\end{array}$ & 2 & 2 \\
\hline \multicolumn{3}{|l|}{ BAE 6 (Pengurangan polusi suara) } \\
\hline $\begin{array}{l}\text { Melakukan upaya dalam mengurangi polusi } \\
\text { suara hingga memenuhi baku mutu tingkat } \\
\text { kebisingan ( } 2 \text { poin). }\end{array}$ & 2 & 2 \\
\hline Jumlah & 18 & 6 \\
\hline
\end{tabular}

Berdasarkan Tabel 9, kategori ini tidak memiliki kriteria prasyarat, sehingga dapat langsung melakukan penilaian terhadap 6 kriteria kredit. Jumlah perolehan nilai pada kategori ini cukup rendah dimana totalnya adalah 6 dari nilai maksimum 18. Nilai yang didapat kurang maksimal karena dalam kawasan belum ada bangunan tersertifikasi Greenship (mendapat nilai 0 pada kriteria BAE 1). Selain itu, penggunaan energi alternatif belum ada diterapkan oleh kawasan. Sumber energi yang digunakan untuk kawasan ini masih berasal dari PLN (kriteria BAE 4 memperoleh nilai 0 ).

Selanjutnya, kriteria mengenai hunian berimbang tidak terpenuhi karena kawasan hanya terdiri dari rumah mewah sehingga pada kriteria 2 mendapat nilai 0 . Terlepas dari kekurangan pada kriteria BAE 1,2 dan 4, kawasan telah mempunyai usaha untuk mengurangi polusi cahaya dengan cara menggunakan lampu jalan dan lampu taman dengan pencahayaan yang rendah. Kawasan juga telah melakukan upaya pengurangan polusi suara dengan melarang kendaraan bermotor yang tidak berkepentingan untuk masuk serta banyaknya 
ditemui pohon besar (jenis trambesi) yang berfungsi untuk meredam kebisingan. Berdasarkan ke dua hal tersebut maka untuk kriteria BAE 5 dan BAE 6 masing-masing mendapatkan nilai 2.

\section{Pengembangan Kedepannya dan Inovasi - Innovation and Future Development (IFD)}

Untuk perolehan nilai pada kategori inovasi pengembangan dan inovasi, berikut ditampilkan pada Tabel 10 .

Tabel 10. Penilaian Kategori IFD

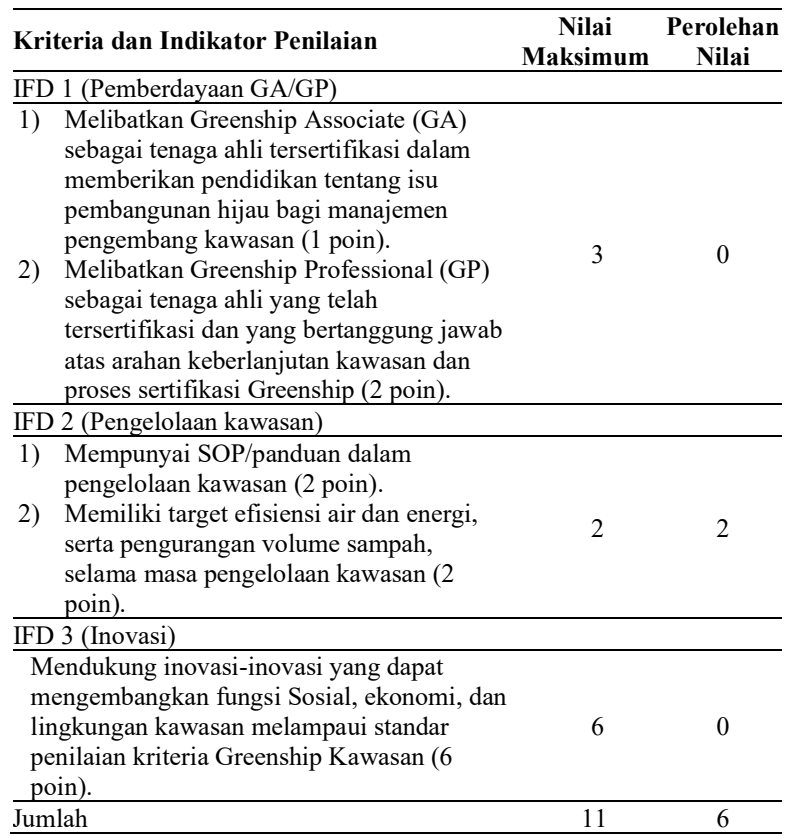

Berdasarkan Tabel 10 dapat dilihat bahwa pada katogori ini terdapat tiga kriteria kredit dan tidak memiliki kriteria prasyarat. Hanya 1 kritera yang terpenuhi dari tiga kriteria yang ada dengan nilai yang diperoleh adalah 2 dari nilai maksimum 11 . Perolehan nilai 2 karena kriteria IFD 2 terpenuhi dimana kawasan memiliki panduan dalam pengelolaanya. Sedangkan untuk kriteria IFD 1 dan IFD 3 masing-masing mendapat nilai 0 , karena pihak pengembang kawasan belum melibatkan tenaga ahli tersertifikasi GA dan GP untuk mewujudkan ke arah pembangunan berkelanjutan kawasan. Selanjutnya kawasan juga belum melakukan inovasi-inovasi yang dapat mengembangkan fungsi lingkungan, sosial dan ekonomi yang melampaui standar penilaian kriteria Greenship Neighborhood.

Secara umum rekapitulasi perolehan nilai beserta bobot pencapaian pada setiap kategori Greenship Neighborhood pada kawasan perumahan Citraland Pekanbaru dapat dilihat pada Tabel 11 dan Gambar 4.
Tabel 11. Total Perolehan Nilai

\begin{tabular}{ccccc}
\hline Kategori & $\begin{array}{c}\text { Nilai } \\
\text { Maks }\end{array}$ & $\begin{array}{c}\text { Perolehan } \\
\text { Nilai }\end{array}$ & $\begin{array}{c}\text { Bobot } \\
\text { Maks }\end{array}$ & $\begin{array}{c}\text { Perolehan } \\
\text { Bobot }\end{array}$ \\
\hline LEE & 19 & 8 & $15 \%$ & $6.5 \%$ \\
MAC & 26 & 0 & $21 \%$ & $0.0 \%$ \\
WMC & 18 & 1 & $15 \%$ & $0.8 \%$ \\
SWM & 16 & 9 & $13 \%$ & $7.3 \%$ \\
CWS & 16 & 10 & $13 \%$ & $8.1 \%$ \\
BAE & 18 & 6 & $15 \%$ & $4.8 \%$ \\
IFD & 11 & 2 & $9 \%$ & $1.6 \%$ \\
\hline Jumlah & 124 & 36 & $100 \%$ & $29 \%$ \\
\hline
\end{tabular}

Berdasarkan Tabel 11, dapat dilihat bahwa secara keseluruhan total perolehan nilai pada kawasan perumahan Citraland Pekanbaru adalah 36, atau bobot pencapaian penerapan Greenship Neighborhood sebesar 29\%. Merujuk pada pada Tabel 2, peringkat terendah Greenship Neighborhood adalah 35\%, untuk peringkat bronze. Hasil yang diperoleh secara umum dari penelitian yang dilakukan menunjukkan bahwa nilai total perolehan yaitu 29\%, dimana tidak mencapai standar minimum yang telah ditetapkan (lihat Tabel 2). Berdasarkan hal tersebut, maka kawasan perumahan Citraland Pekanbaru pada saat penelitian dilakukan belum memenuhi peringkat penerapan Greenship Neighborhood meskipun mereka telah mengusung konsep green and clean.
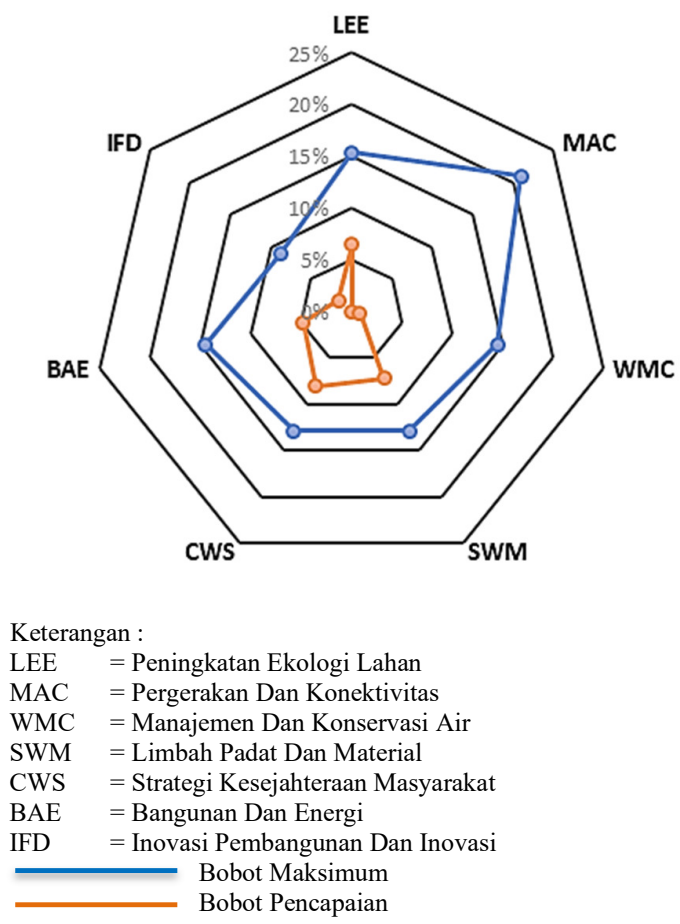

Gambar 4. Grafik bobot pencapaian terhadap bobot maksimum.

Berdasarkan Gambar 4, dapat dilihat bahwa kategori CWS (strategi kesejahteraan masyarakat) merupakan kategori yang bobot pencapaiannya mendekati bobot maksimum, sedangkan bobot pencapaian untuk kategori lainnya dipandang belum 
Cantilever $\mid$ Volume: 10 Nomor: 01 April $2021 \mid$ ISSN: 1907-4247 (Print) $\mid$ ISSN: 2477-4863 (Online) $\mid$ Website: http://cantilever.id

Sapitri \& Zarnol Aziz | Penilaian Kawasan Perumahan dengan Pendekatan Konsep Berkelanjutan (Greenship Neighborhood Assessment)

maksimal. Contohnya, untuk kategori WMC (manajemen dan konservasi air) telah terpenuhi namun memperoleh bobot yang minim sebesar $1 \%$. Kemudian terdapat kategori yang belum diterapkan $(0 \%)$ yaitu kategori MAC (pergerakan dan konektivitas).

Untuk memaksimalkan penerepan setiap kategori Greenship Neighborhood agar menuju kawasan yang berkelanjutan, maka perlu beberapa upaya yang harus dilakukan oleh pihak kawasan perumahan Citraland Pekanbaru. Beberapa upaya yang dapat dilakukan antara lain penggunaan air alternatif, energi alternatif, memiliki bangunan hijau yang telah tersertifikasi Greenship, dan yang paling utama adalah menyediakan jalur khusus pejalan kaki, serta upaya terkait pengurangan volume limbah padat (sampah) dan cair. Terkait limbah, hal yang serupa juga menjadi concern pada laporan pencapaian SDGs tahun 2019 poin tujuan kota dan pemukiman yang berkelanjutan. Beberapa kebijakan dalam penanganan sampah antara lain: pengelolaan sampah sejak dari hulu hingga ke hilir dengan prinsip pengurangan dan penggunaan kembali; penguatan kampanye pengurangan sampah; penguatan kapasitas pemerintah daerah, regulasi dan lembaga pengelola sampah; pemantauan, evaluasi dan penegakan hukum (Kementerian Perencanaan Pembangunan Nasional/Badan Perencanaan dan Pembangunan Nasional, 2019).

\section{KESIMPULAN}

Secara umum, terdapat enam dari tujuh kategori penilaian Greenship Neighborhood yang telah diterapkan, yaitu peningkatan ekologi lahan (LEE), manajemen dan konservasi air (WMC), limbah padat dan material (SWM), strategi kesejahteraan masyarakat (CWS), bangunan dan energi (BAE), dan inovasi pembangunan (IFD). Sedangkan, terdapat satu kategori yang tidak diterapkan yaitu mengenai pergerakan dan konektivitas (MAC).

Perolehan nilai dan bobot setiap kategorinya adalah kategori LEE memperoleh nilai 8 dengan bobot $6,5 \%$, kategori MAC memperoleh nilai 0 dengan bobot $0 \%$, kategori WMC memperoleh nilai 1 dengan bobot $0,8 \%$, kategori SWM memperoleh nilai 9 dengan bobot $7,3 \%$, kategori CWS memperoleh nilai 10 dengan bobot $8,1 \%$, kategori BAE memperoleh nilai 6 dengan bobot 4,8\%, dan kategori IFD memperoleh nilai 2 dengan bobot $1,6 \%$. Secara keseluruhan untuk total perolehan nilai adalah 36 dari nilai maksimum 124, dengan bobot pencapaiannya adalah $29 \%$. Berdasarkan nilai tersebut, kawasan perumahan Citraland Pekanbaru tidak memenuhi salah satu peringkat Greenship Neighborhood yang telah ditetapkan oleh GBCI (baik platinum, gold, silver, atau bronze).

Meskipun isu green bukan menjadi hal yang baru lagi di Indonesia, namun implementasinya belum dilakukan secara maksimal. Rekomendasi yang dapat diberikan adalah agar konsep green baik pada kawasan perumahan, kawasan industrial, kawasan komersial ataupun gedung perkantoran dapat sejalan dengan implementasi konsep dan prinsip "green" itu sendiri. Hal tersebut dibuktikan dengan adanya sertifikasi Greenship yang dikeluarkan oleh GBCI.

\section{REFERENSI}

Accord, B. (2005). Bristol Accord Conclusions of Ministerial Informal on Sustainable Communities in Europe, Presidency, (December), pp. 6-7.

Blum, A \& Grant, M. (2006). Sustainable Neighbourhood: Assessment Tools For Renovation and Development, Journal of International Research Publications, 1, pp. 1-15. Available at: https://uwerepository.worktribe.com/OutputFile/104303 2.

Dinas Penanaman Modal dan Pelayanan Terpadu Satu Pintu (2019). Jumlah Perumahan di Kotamadya Pekanbaru. Pekanbaru.

GBCI (2015) GREENSHIP Neighborhood Version 1.0.

Hidayat, F. (2015). Lima Kota Terbaik untuk Investasi Properti, beritasatu.com. Available at: https://www.beritasatu.com/archive/260991/lima-kotaterbaik-untuk-investasi-properti. Diakses: 10 Januari 2020.

Kementerian Perencanaan Pembangunan Nasional/Badan Perencanaan Pembangunan and Nasional (2019). Pelaksanaan Pencapaian TPB/SDGs Indonesia: Pencapaian Tujuan 11 Kota dan Pemukiman yang Berkelanjutan, sdgsindonesia.or.id.

Kementrian PUPR - Ditjen Cipta Karya (2016). Konsep Pembangunan Berkelanjutan, sim.ciptakarya.pu.go.id. Available http://sim.ciptakarya.pu.go.id/p2kh/knowledge/detail/pe mbangunan-berkelanjutan.

Kusumaputera, A. R. (2011). Grup Citra Luncurkan Perumahan Citraland Pekanbaru', Kompas.com, 10 March. Available

at:https://properti.kompas.com/read/2011/03/10/223830 21/grup.ciputra.luncurkan.perumahan.citraland.pekanba ru. Diakses: 25 Agustus 2019.

Ronim, A. \& Talidah, C. I. (2019). Pengukuran Greenship Kawasan (Built Project) Versi 0.1 Pada Kawasan Wisata Bandar Ecopark Di Kabupaten Batang, Jurnal Arsitektur ARCADE, 3(1), p. 14. doi: 10.31848/arcade.v3i1.174.

Sadjarwo, I. \& Sutandi, A. (2017). Analisis Penerapan Greenship Neighborhood Version 1.0 pada Kawasan Perumahan, Prosiding Konferensi Nasional Teknik Sipil 11, pp. 55-65. 